\section{Optimized RAPD}

Analysis Generates HighQuality Genomic DNA Profiles at High Annealing Temperature

BioTechniques 28:52-54 (January 2000)

Techniques such as arbitrarily primed polymerase chain reaction (APPCR) (11), random amplified polymorphic DNA (RAPD) (12) and DNA amplification fingerprinting (DAF) (7) are powerful tools for genetic mapping, taxonomic and phylogenetic investigations and for the detection of various types of DNA damage and mutation (2,3). Nevertheless, the arbitrary nature of the DNA polymerization catalyzed in these methods has drawn criticism because of the low annealing temperature used with short primers. In this study, the RAPD method was optimized at an annealing temperature of $50^{\circ} \mathrm{C}$ for 10 -mer primers. The main advantage of high stringency conditions is that nonspecific reactions are significantly reduced. Thus, protocols that use a high annealing temperature should be always preferred if the sensitivity of polymorphism detection is not jeopardized.

Although DNA profiles have been generated at a high annealing temperature for short primers $(5,6,8)$, an optimization study using high annealing temperature has rarely been attempted, to our knowledge. Indeed, it is generally believed that repeating a PCR assay is jeopardized by annealing temperatures higher than the $T_{d}$ of the oligonucleotide primer. For instance, it has been reported that annealing temperatures above $40^{\circ} \mathrm{C}$ prevent amplification by 10 -mer primers (12). Relatively low annealing temperatures $\left(34^{\circ} \mathrm{C}-36^{\circ} \mathrm{C}\right)$ are used in RAPD to ensure a maximal number of primer binding events and the consequent generation of many amplified DNA fragments for analytical purposes. However, the low stringency of the accompanying DNA hybridization can result in the formation of spurious amplifications (9) that affect both the reproducibility (8) and the detection of Mendelian inheritance patterns (4).

The RAPD method was developed

Table 1. Optimized Conditions to Produce High-Quality RAPD Profiles at High Annealing Temperatures

\begin{tabular}{|c|c|}
\hline PCR Parameters & Optimized Conditions \\
\hline Annealing temperature & $50^{\circ} \mathrm{C}-54^{\circ} \mathrm{C}(50)$ \\
\hline $\mathrm{Mg}^{++}$concentration & 3-6 mM (5.11) \\
\hline dNTP concentration & $0.33-0.44 \mu \mathrm{M}(0.33)$ \\
\hline Primer concentration (10-mer) & $1.0-2.0 \mu \mathrm{M}(2.0)$ \\
\hline $\begin{array}{l}\text { Number of native Taq DNA } \\
\text { polymerase units }\end{array}$ & $0.08-0.12 \mathrm{U} / \mu \mathrm{L}(0.112 \mathrm{U} / \mu \mathrm{L})$ \\
\hline Amount of DNA & $0.008-4 \mathrm{ng} / \mu \mathrm{L}(0.2-0.8 \mathrm{ng} / \mu \mathrm{L}))$ \\
\hline PCR buffer & $\begin{array}{r}1 \times\left(10 \mathrm{mM} \text { Tris- } \mathrm{HCl} \mathrm{pH} 8.8 \text { at } 25^{\circ} \mathrm{C}\right. \\
50 \mathrm{mM} \mathrm{KCl}, 0.08 \% \text { Nonidet } \mathrm{P} 40)\end{array}$ \\
\hline Bovine serum albumin & $0.1 \mu \mathrm{g} / \mu \mathrm{L}$ \\
\hline Thermal cycling conditions & $\begin{array}{l}\text { First cycle, denaturation at } 95^{\circ} \mathrm{C} \text { for } \\
4 \text { min, followed by } 39 \text { cycles of } \\
\text { denaturation at } 95^{\circ} \mathrm{C} \text { for } 1 \mathrm{~min} \text {, } \\
\text { annealing at } 50^{\circ} \mathrm{C} \text { for } 1 \mathrm{~min} \text {, exten- } \\
\text { sion at } 74^{\circ} \mathrm{C} \text { for } 1 \mathrm{~min} \text {, except the } \\
\text { final extension at } 74^{\circ} \mathrm{C} \text { for } 10 \mathrm{~min} \text {. }\end{array}$ \\
\hline \multicolumn{2}{|c|}{$\begin{array}{l}\text { PCR reagents were obtained from Immunogen International (Sunderland, } \\
\text { England, UK) and 10-mer primers from Operon Technologies (Southampton, } \\
\text { England, UK). Figures in parentheses represent conditions used throughout the } \\
\text { present study. Final reaction volume was } 25 \mu \mathrm{L} \text {. For more details, refer to } \\
\text { Reference } 2 \text { or } 3 .\end{array}$} \\
\hline
\end{tabular}

as a result of the sequential and systematic analysis of the RAPD protocol performed by the variation of annealing temperatures, DNA purity, primer sequence and the relative concentration of each PCR reagent. The objective was to generate reproducible DNA profiles of high discrimination with a maximum number of bands, good product yield and clarity, while reducing the occurrence of spurious amplifications in the negative control reactions. Initially, the parthenogenetically produced offspring of Daphnia magna (clone 5) (2) was chosen to eliminate the possibility of confusing genomic changes from sexual reproduction. The optimization work was also performed using other species belonging to the bacteria, plant and animal kingdoms. Table 1 shows the results of the optimization study. Contrary to RAPD methods using low annealing temperatures, consistent genomic profiles were generated when component concentrations were sub- jected to variation, within the predefined optimal conditions.

DNA of good purity and free from other macromolecules and inhibitory compounds produces clear and discriminatory RAPD profiles. For the bulk of our experiments, genomic DNA prepared by a standard phenol/chloroform extraction purification was sufficient to produce RAPD profiles of high quality; profiles of identical quality were obtained using either phenol chloroform or caesium chloride extracted DNA. Further experiments also confirmed that the storage buffer (analytical grade water or $1 \times$ Tris-Borate-EDTA buffer) had no influence on RAPD profiles. In addition, under optimized conditions, identical RAPD profiles were generated whenever the DNA extraction or PCR was performed. The DNA concentration was also found to be crucial in the production of reproducible genomic profiles, not only to ensure the largest number of amplified bands but also to 

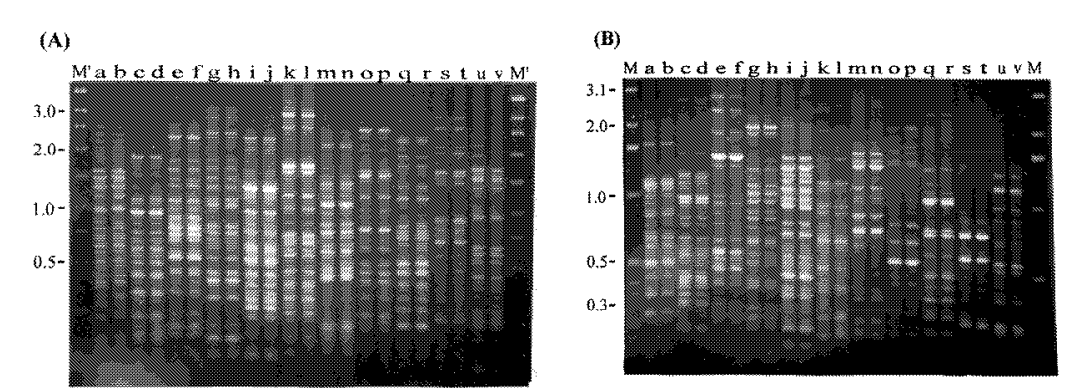

(C)

(D)
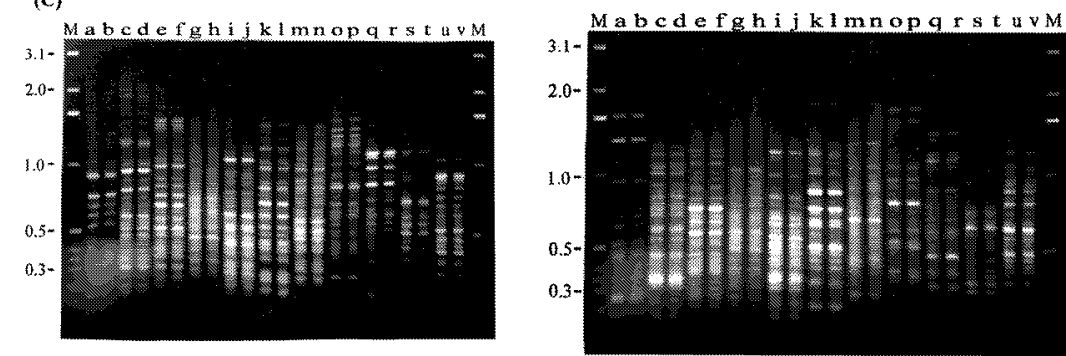

Figure 1. RAPD profiling of genomic DNA templates. (A) Daphnia magna, phenol-chloroform extracted DNA (2); (B) Escherichia coli, on (B), (C) and (D), caesium chloride DNA (Sigma, Poole, England, UK); (C) calf thymus; and (D) Human placental DNA using 10-mer primers. On (A), M'= $1 \mathrm{kbp}$ ladder (Immunogen International), while on (B), (C) and (D) M= 1 kbp ladder (Life Technologies). Molecular sizes, in kilobases, of selected bands are indicated on the left of each figure. Lanes a-b, OPA9; c-d, OPB1; e-f, OPB5; g-h, OPB6; i-j, OPB7; k-1, OPB8; m-n, OPB10; o-p, OPB11; q-r, OPB12; s-t, OPB14; and $\mathrm{u}-\mathrm{v}$, OPB17. Sequences for each primer can be obtained from http://www.operon.com. Lanes a,c,e, etc. $=5 \mathrm{ng}$ template; b,d,f, etc. $=20 \mathrm{ng}$ template.

confirm the fidelity of the PCR condition. If profiles from the same genomic template or from different individuals of the same species vary, the reproducibility of the assay should be confirmed by repeating the PCR using two different template concentrations that differ by at least twofold (11). If profiles still vary, then results should always be questioned.

Although the choice of the 10-mer primers is generally crucial to the success of any RAPD protocol, our set of 11 primers generated high-quality profiles using genomic DNA extracted from D. magna, E. coli (strain B), calf thymus and human placenta (Figure 1). Profiles generated using template DNA at both 5 and $20 \mathrm{ng}$ were identical, and demonstrated the high reproducibility of the methodology and the lack of template-dependent amplification artifacts. Regarding the magnesium concentration, a satisfactory reproducibility was obtained with 3-6 mM Mg+, as already reported by earlier studies (5). Finally, one of our major goals was to minimize the primer polymerization generated in negative controls $(1,10)$. By varying the dNTP concentrations between otherwise identical reaction mixtures, it was shown that "dirty" negative controls could be significantly reduced. A dNTP concentration of 0.33 $\mathrm{mM}$ produced many bands with a complete or partial reduction in spurious amplifications in reactions without genomic DNA templates (1).

In conclusion, our RAPD protocol was found to generate high-quality genomic DNA profiles from phylogenetically different groups of organisms (bacteria, plants and animals) using the same set of primers. Since RAPD reactions are performed at a high annealing temperature, spurious amplifications are kept to a minimum and consistent profiles are generated when component concentrations are within the predefined optimal range.

\section{REFERENCES}

1.Atienzar, F., P. Child, A. Evenden, A. Jha, D. Savva, C. Walker and M. Depledge. 1998.

Application of the arbitrarily primed poly- 
merase chain reaction for the detection of DNA damage. Mar. Environ. Res. 46:331-335.

2.Atienzar, F., M. Conradi, A. Evenden, A. Jha and M. Depledge. 1999. Qualitative assessment of genotoxicity using random amplified polymorphic DNA: comparison of genomic template stability with key fitness parameters in Daphnia magna exposed to benzo(a)pyrene. Environ. Toxicol. Chem. 18:2275-2282.

3.Atienzar, F., B. Cordi, M. Donkin, A. Evenden, A. Jha and M. Depledge. Comparison of ultraviolet induced genotoxicity detected by RAPD with chlorophyll fluorescence and growth in a marine macroalgae, Palmaria palmata. Aquat. Toxicol. (In press).

4.Ayliffe, M.A., G.J. Lawrence, J.G. Ellis and A.J. Pryor. 1994. Heteroduplex molecules formed between allelic sequences cause nonparental RAPD bands. Nucleic Acids Res. 22:1632-1636.

5.Bentley, S. and B.J. Bassam. 1996. A robust DNA amplification fingerprinting system applied to analysis of genetic variation within Fusarium oxysporum f.sp. cubense. J. Phytopathol. 144:207-213.

6.Caetano-Anollés, G. 1998. DAF optimization using Taguchi methods and the effect of thermal cycling parameters on DNA amplification. BioTechniques 25:472-480.

7.Caetano-Anollés, G., B.J. Bassam and P.M. Gresshoff. 1991. DNA amplification fingerprinting using very short arbitrary oligonucleotide primers. Biotechnology 9:553-557.

8.Ellsworth, D.L., K.D. Rittenhouse and R.L Honeycutt. 1993. Artifactual variation in randomly amplified polymorphic DNA banding patterns. BioTechniques 14:214-217.

9.Mullis, K.B. 1991. The Polymerase Chain Reaction in an anemic mode: how to avoid cold oligodeoxyribonuclear fusion. PCR Methods and Applications 1:1-4.

10.Ruano, G., W. Fenton and K.K. Kidd. 1989. Biphasic amplification of very dilute DNA samples via booster PCR. Nucleic Acids Res. 17:5407.

11.Welsh, J., D. Ralph and M. McClelland. 1995. DNA and RNA fingerpinting using arbitrarily primed PCR, p. 249-276. In M.A. Innis, D.H. Gelfand and J.J. Sninsky. (Eds.), PCR Strategies. Academic Press, San Diego.

12.Williams, J.G.K., A.R. Kubelic, K.J. Livak, J.A. Rafalski and S.V. Tingey. 1990. DNA polymorphisms amplified by arbitrary primers are useful as genetic-markers. Nucleic Acids Res. 18:6531-6535.

Financial support from the European Commission (Marie Curie Grant No. ERB4001-GT-97-0136) is gratefully acknowledged. Address correspondence to Franck Atienzar, Department of Biological Sciences and Plymouth Environmental ResearchCenter (PERC), University of Plymouth, Drake Circus, Plymouth, PL48AA, England, UK. Internet:fatienzar@plymouth.ac.uk

Received 28 June 1999; accepted 19 October 1999.
F. Atienzar, A. Evenden, A. Jha, D. Savva ${ }^{1}$ and M. Depledge University of Plymouth Plymouth, England, UK ${ }^{1}$ The University of Reading Reading, England, UK

\section{Improved Analysis of Promoter Activity in Biolistically Transformed Plant Cells}

BioTechniques 28:54-58 (January 2000)

A common way to analyze gene expression involves the use of transgenic plants. Transient assays that use particle bombardment (9) are a powerful alternative to rapidly evaluate gene expression in intact plant tissues. If the particular system in use has been validated by another approach, the results provide a meaningful indicator of the expression of stable genes in plants. Even for verified transient assay systems, a critical problem often associated with particle bombardment is that of high data dispersion. On the other hand, the choice of the assay (histochemical or fluorometric) used to quantify promoter activity in gus-based constructs could lead to misinterpretation of the data because of the different sensitivities for GUS detection among assays. The aim of this work was to find a way to decrease data dispersion and to evaluate the consistency of the two assays of GUS activity used to determine the promoter activity in transient assays.

To address the data dispersion problem, we used the $C l$ and $B$-Peru genes from maize as internal controls. These genes code for transcriptional factors that activate the anthocyanin biosynthetic pathway $(1,10)$. The level of anthocyanin was used as a visual marker to select only samples with high levels of transformed cells. A major factor causing data dispersion is the unequal dispersion of particles among different bombardments and among distinct samples in the same bombardment. Internal controls coding for other reporter enzymes under the control of constitutive promoters are generally used to normalize the data dispersion. However, when using internal controls, it is desirable to identify efficiently transfected samples before undertaking the laborious process of protein extraction and quantification of the promoter activities of the test and control constructs.

In these experiments, we evaluated the co-bombardment of the test DNA construct together with constructs containing the $C l$ and $B$-Peru genes $(1,10)$. After bombarding tissues from maize, wheat, petunia, pea and white clover with these two genes under the control of the cauliflower mosaic virus (CaMV) $35 \mathrm{~S}$ promoter, the transformed cells become colored as a result of anthocyanin accumulation and can be seen with the naked eye $(1,2,7,10,11,13)$.

The constructs p35SC1, pB-Peru (anthocyanin accumulation) and pAH18 (luciferase production) were used as internal controls, and p699 was used as a test construct to direct GUS production. GUS activity is expressed as pmol 4-methylumbelliferone (4-MU) $\mathrm{min}^{-1}$ $\mathrm{mg}^{-1}$. Both $\mathrm{p} 35 \mathrm{SC} 1$ and $\mathrm{pB}-$ Peru contain the CaMV 35S promoter and the first intron of maize Adh1, fused to the $C 1$ and $B$-Peru gene coding regions, respectively (kindly provided by $\mathrm{S}$. Wessler). The pAH18 contains the maize ubiquitin promoter and its first intron fused to the firefly luciferase coding region (5). The p699 is a deletion of the Hrgp promoter obtained from an AC1503 maize genomic clone (EMBL Accession No. AJ131535) with the $3^{\prime}$ end at +16 and the $5^{\prime}$ end at -699 (numbering relative to the ATG start codon), fused in frame to a $g u s A / 3^{\prime}$ NOS fragment (12). The maize Hrgp gene codes for a hydroxyproline-rich glycoprotein that is present in cell walls (15), and the promoter shows high activity in young shoots and immature embryos (12).

When intact maize tissues with irregular shapes were bombarded, there was a high level of data dispersion, even among samples in the same petri dish. In a representative experiment (Figure 1), young seedlings were bom- 